\title{
Challenges Encountered by Physical Education Teachers on Blended Learning Approach in Physical Education in times of Covid 19 Pandemic
}

\author{
Geen Ann J. Rosell \\ geenann.rosell@gmail.com \\ ${ }^{1}$ Kalilangan National High School, \\ ${ }^{1}$ Kalilangan, Bukidnon, 8718 Philippines
}

\begin{abstract}
The study aimed to explore the challenges encountered by Physical Education Teachers on Blended Learning Approach in Physical Education in times of COVID-19 Pandemic. The challenges encountered was brought due to the emergence of COVID-19 Pandemic. The research is qualitative in nature and used descriptive narrative method which primarily aimed to gain understanding of the challenges encountered by Physical Education Teachers on Blended Learning Approach in Physical Education in times of COVID-19 Pandemic. The participants of the study were purposively selected. The Teachers teaching Physical Education subjects participated in an interactive interview and answered the questions in the interview schedule which was the semi-loosely structured interview. The Inductive Thematic Approach was adapted utilizing the steps in Colaizzi Method to interpret the narrative account of the informants on challenges encountered by Physical Education Teachers on Blended learning approach in times of COVID-19 Pandemic. Based on the result of the study, the following themes had been generated: First, the Teaching- Learning Experiences in which they had encountered Lack of Parental Support and Involvement, Lack of Communication and Comprehension, Poor Quality of Outputs. Second, is the Technical Support which includes having Poor Internet Connection, Unavailability of Technological Gadgets and Poor Technical Literacy. With regards to the challenges encountered a Proposed Intervention Plan may be utilized.
\end{abstract}

Keywords: Blended Learning; Challenges; Intervention Plan; Modality; Pandemic.

\section{Introduction}

Adopting a new teaching method can be difficult, especially if you're an early adopter in a lowresource setting. Due to this health threat COVID-19 pandemic the Department of Education have proposed different Approaches to learning. Educators had been exploring ways to increase student participation and engagement in the learning process. Blended Learning is one of the learning delivery Modes raised by the higher authorities that schools can adopt. This mode refers to a learning delivery that combines face-to-face with any, or a mix of, Modular Distance Learning, Online Distance Learning, and Television/Radio-Based Instruction. Blended learning will enable the schools to limit face-to-face learning, ensure social distancing, and decrease the volume of people outside the home at any given time. 
Teachers must not only consider the elements of effective learning and find the right blend of online and in-class activities when designing a blended course; they must also address some of the issues that arise when using the approach, such as a lack of technology and the time management skills required for success in a blended format. Teachers may be under a lot of stress as a result of these issues. When instructors are under a lot of stress, their pupils' social adjustment and academic performance suffer. Furthermore, when a teacher is overworked or anxious, they have less time to focus on the pupils and the lectures. To avoid a situation like this, research must be undertaken to identify teachers in a certain setting.

Changing a traditional course to a blended course is a tough process that necessitates instructors with a diverse range of ideas on how to deliver education. Despite how simple it may appear; even experienced teachers struggle with the problem of attaining balance and harmony between the two approaches. re-examining course goals; constructing integrated and linked online and face-to-face activities; determining ways to assess students' knowledge and mastery of the course material; and establishing opportunities for students to connect are among the tasks that faculty must undertake in the course transformation process.

Based on the considerations of the new normal education to what modes of learning delivery to be implemented, our school adapted the blended learning modality in the teaching of Physical Education Classes. This learning Approach brought teachers to experience difficulties in adjusting in the combination of modular, Radio- based instruction and Online Teaching. More over teacher suffer from the time preparations and technical support and many more. Due to the demand of continuing education even this pandemic teacher is striving hard finding means just to comply to the mandate of Section 1, Article XIV of the 1987 Constitution for the state to protect and promote the right of all citizens to quality education at all levels, and to take appropriate steps to make such education accessible to all. In order to take part and could offer help in the situation our school were facing under Blending learning Approach in teaching I am motivated to conduct a study by exploring the challenges encountered by Physical Education Teachers on blended learning Approach in the teaching of physical education in times of COVID 19 Pandemic.

I was moved to offer help as to the best of my ability to somehow lessen the burden of the teachers in the teaching of Physical Education by exploring the challenges they experience during the pandemic. Thus, result of the study were the basis for developing an intervention Plan. This formulation of proposed Intervention Plan must be utilized to address the gap.

The study was conducted to explore the challenges encountered by the Physical Education Teachers on Blended Learning Approach in teaching Physical Education in times of COVID-19 pandemic. Therefore, the development of Intervention Plan based on the explored experiences of the Teachers under Blended learning Modality must be implemented to be benefited by the Physical education Teachers. administrators and students.

\section{Methodology}

Methodology of the present undertakings which focus on the challenges encountered by the Teachers teaching Physical Education during covid-19 pandemic. This includes presenting the methods of the study, locale of the study and the informants of the study, research instruments to be used, data gathering procedure, and the data analysis to be utilized in this study. It describes the processes that were used to answer the problems of the present study. 


\subsection{Designs}

I employ the qualitative approach utilizing descriptive narrative method which focused on the challenges encountered by the Teachers under Blended learning Approach in Physical Education in time of COVID-19 pandemic. The research used open ended question or semi-loosely structured interview. This study also used descriptive analysis method in describing a group of people, a phenomenon or event. It described who encountered the problem, how widespread the problem and how long the problem existed. The study describes the experiences encountered by the Teachers under Blended learning Approach in Physical Education in time of COVID-19 pandemic thus formulating the theme through coding which will be used in designing an Intervention Plan.

\subsection{Environment}

The research environment was the Kalilangan National High School, a Public High School specifically located at Ninoy Aquino, Kalilangan in province of Bukidnon, region X - Northern Mindanao. It has a land area of about 1.8 hectares. The present working force are 120 compost of administration, faculty and staff. Kalilangan National High School is one of the performing Schools in the Division of Bukidnon, having a multi awarded faculties and students from local up to national level.

\subsection{Participants}

The participants were purposely selected for this study. Purposive sampling technique were used in determining the number of informants for this study. There were 6 out 13 Physical Education teachers were interviewed in a face-to-face interaction focusing on the challenges encountered in teaching Physical Education using the Blended Learning Approach. These select informants were considered experienced base on the length of service rendered and knowledgeable enough in the field of Teaching Physical Education.

\subsection{Instrument}

The instrument used in the study was the interview schedule an open-ended question. According to (Flick 2002) interview schedule is a written list of question, open-ended, prepared by the interviewer in a face-to-face interaction. Qualitative data were used as method of evaluation.

\subsection{Data collection}

This part was a description of the activities in gathering data. This involved the sending of communication and conduct of an interview.

Following the step-by-step process in gathering the data, I sent a communication letter to all the proposed authority involved in the conduct of study. asked permission to the school principal to conduct the study in Kalilangan National High School and to the informants by sending a consent letter to the participants and letter of transmittal address to the School Principal. I explained thoroughly to the participants during the interview schedule the purpose of the interview to ensure full support from them and also for the completeness of data needed in the study. 
In this study the data were analyse using Inductive Thematic Analysis utilizing the seven steps in Colaizzi Method. This was also used in interpreting the data from the informants. The following were the step-by-step process in analysing the data. First, in order for me to familiarize the narrative accounts of the informants I do the readings several times to attain the general sense of the challenges encountered by the informants. Second, the significant statements were extracted from the informant's transcript that pertains to the challenges encountered by Physical Education Teachers in Teaching Physical Education under Blended Learning Approach in times of pandemic. Third, significant statement was clustered in to sub-theme. Fourth, the sub-themes were then analysed into themes. Fifth, the result of the study was then integrated into an exhaustive description of the phenomenon under this study. Sixth, the fundamental structure of the phenomenon was described. Seventh, review the fundamental structure of the informant's statements for verifications whether the results really captured the experiences encountered by the Teachers under Blended Learning Approach in Physical Education in times of COVID-19 pandemic.

\section{Result and discussion}

Challenges Encountered by Physical Education Teachers on Blended learning Modality in Teaching Physical Education in times of COVID-19 pandemic.

\section{CHALLENGES ENCOUNTERED}

Challenges means the situation that are being faced with, something that needs great mental or physical effort in order to be done successfully and therefore tests a person's ability. The significant theme generated from this study are the experiences of teachers in Teaching-learning and in the Technical Support. Along with these themes are the sub-themes Poor Internet Connection, Poor Quality of Outputs, Unavailability of Technological Gadgets, Lack of Parental support and involvement and Poor Technical Literacy.

\section{Teaching-Learning Experiences}

Teaching-learning experiences is generally described by the informants having lack of parental support and involvement, lack of communication and comprehension. Teaching at this moment is extraordinarily hard. Teachers provide guidance on pursuing higher education and participating in events that encourage growth in a young person. The importance of teachers as guides for children as they consider furthering their education is immeasurable. In the teaching of physical education, teacher shows unique responsibilities in the school physical activity program to ensure that students are physically active within the Physical Education classes. Along with the teaching learning experiences, the Kalilangan National High School Teachers teaching Physical Education have also experience difficulty in the teaching- learning process. The following are:

Lack of Parental Support and Involvement. Parental involvement as to the informant's accounts refers to the attentiveness of the parent to the call and having lack of support due to their financial state. Parents involvement and support has a powerful impact on their attainment and adjustments of the learners. To this regard's teachers are expecting supports from parent especially in this home-school partnership. Teachers experience in some of their parents showing little support or nothing at all in the educative process. Some just let their children get their own learning module in school. Due to financial problem of the family their support was limited. Informant also said that there are parents who don't even attended orientation and 
meetings. Further challenges are shown based on the informants' statements.

\author{
"Some parents have insufficient support due financial status" \\ "Parent attendance during orientation is limited and for that reason \\ some instructions from us teachers where neglected" \\ i-\#2 \\ "My students are no longer in school and trying to contact parent's \\ attention but not answering my call" \\ i-\#3
}

"Some of my parents are busy making a living and tend to forget their responsibility in school in attending their child's needs.

I-\#

According to (Comer \& Haymes 1997) Children learn best when the significant adults in their lives like parents, teachers, and other family and community members works together to encourage and support them. Early studies often show positive links between parental involvement in school and students' progress. However, Sacker et al (2002) uttered that involvement is assumed to be influenced by material deprivation and parental aspiration. This entails that the poorer are people's circumstances the more difficult it is assumed to be to support a child's educational development. The latter, parental aspiration, is in turn influenced by the child's evident achievement. The more the child achieves, the greater is the parental expectation.

Collaborations between classroom teachers, parents, and other family members of students at a school are known as family-school partnerships. Mutual trust and respect, as well as shared responsibility for the education of the school's children and young people, are the foundations of successful partnerships. It is not always easy to form family-school relationships. It necessitates effort and time. Many families will need special arrangements or additional support to allow them to become actively involved in their children's school lives and to help their children get the best out of school due to stresses and circumstances.

This implies that home-school partnership should work effectively to maximize the learning experience of the students. The teaching staff and administrator should find means to reach out parents emphasizing the importance of their involvement in the educative process. Families must be accepted as full participants in the educational process, and schools must go out of their way to reach out to them. On the other hand, families must commit time and effort to helping their children at home and at school. It's well worth the time and work it takes to re-establish these connections. Parental involvement may aid in the development and achievement of pupils. It is feasible, desirable, and advantageous.

Lack of communication and comprehension. Based on the informant's account Communication and Comprehension has something to do with the ability of the person or individual to follow schedules, instructions given and time allotment in doing the task. This is for the purpose of bringing uniformity and harmony in the action. Informants also expressed: 
"My students start answering their module at eleventh our this is the reason why very few activities were being answered besides, they are not following instructions in the Weekly home learning Plan"

i-\#1

"Some Parents are not following the distribution and retrieval Schedule. They were late in submission" i-\#2

"Some students are not following instructions, they set their own deadlines of submitting their requirements" i-\#3

According to Berge (2013), due to the geographical isolation of students and teachers, a vital connection in distant education communication was lacking. It was believed, however, that it was the job of the educational institution to compensate for communication hurdles in order to prevent student dropout and help students integrate their academic and social experiences with their education. Students' feelings of isolation are another significant communication challenge addressed in the distance education literature, which will take some time to understand how to alleviate by allowing all students and instructors to share their perspectives, ask questions, and generally create a sense of belonging to a group. However, as students became more familiar with online learning and communication, feelings of isolation faded and were replaced with feelings of intimacy and kinship.

Active listening is an important aspect of effective communication. I believed that we cannot engage with someone if we are not listening to them. Planning ahead of time for teachers could bring advantage to avoid problems in the future. In this situation teachers and parent should work together to support students accomplished the desirable task at a given time. Parent should take part when children are start learning at home. Constant communication and giving feedback of educators will be very beneficial to facilitate learning. Motivating and encouraging students to work hard and miss fewer lessons, parent, teacher and student relationships can keep struggling students from falling behind and close the achievement gap in education especially in this new normal situation.

The study suggests that teachers must prepare a classroom management plan to ensures all the activities are designed effectively. All instruction must be well understood to both parents and student for guidance thus, lead to a better result. Building good working relationships with parents and students, communicating with them appropriately at beginning of the grading period by conducting an orientation, weekly monitoring of student's progress could be a great help to keep in touch with them ensuring quality education.

Poor quality of outputs. Is generally defined as the manifestations of incomplete student output and answered activities leading to the teacher's difficulty in assessment. In Physical education classes skills performance also is extremely important and part of their output submission since it helps to prove that students are applying the information they have gained through application. In this regard schools have been identified as locations in which physical activity (PA) promotion should occur (Pate, Davis, Robinson). Teacher have a hard time assessing and evaluating the learning of the student because of the incomplete output submitted during the retrieval period. Some related problems are associated with the informant's statement during the interview. 
"While checking their notebooks there are numbers of unanswered activities"

i-\#2

"One of my students I have talked last time asking the reason why very few activities in his notebook, he just smiled to me and said it's very difficult ma'am and a lot of activities need to be answered" i-\#3

"Very hard to give grades because of their Incomplete outputs" i-\#4

"it's really hard in my part to assess students especially in giving their grades, I am not even sure if they are the one answering their modules. Not all activities were answered..." i-\#5

According to (Adam, 2004), Learning outcomes are written statements of what the successful student/learner is expected to be able to achieved at the end of the programmed module/course unit. Without output, teachers have no way of knowing that the students understand the information to a level necessary to ensure that they can demonstrate the learning (Stone, McKenzie \& Young, 2006). The range of forms of student assessment used across the sector is growing (Bryan and Clegg 2006), and Knight (2002) argues that we 102 A Connected Curriculum for Higher Education need to make students' experiences of assessment as authentic, effective and efficient as possible.

We, teachers are very much aware of the level and standard required to successfully pass the subject. Output is the learning product which refers to the leaning output of the students after answering SelfLearning Module at end of the week. This output is the indication that learning has taken place. However due to unexpected situation like today where lot of restriction are being implemented to contained the virus one of the many is the face-to-face interaction. The student outputs are influence by how active the students in learning and answering the module. This positive engagement of the student in the educative process could possibly produce a quality learning outputs thus, making teacher work easier in the assessment method.

The study entails that the completion of students output should be given emphasis for the assessment of student progress, in giving grades and for further learning experiences. On the other hand, incomplete output could be the result of insufficient time and difficulties encountered in answering the SelfLearning Module. Submission of incomplete output maybe due to distractions, and lack of focus. It also suggests that teachers should expand number of ways to communicate with students. Restructuring teaching methods. Both teaching and learning methods must be restructured for students if want is to improve their grades, and have a bright academic future.

\section{Technical Support}

It is defined as the difficulties encountered by the Physical Education Teachers on Blended Learning Approach in the Teaching of Physical Education having Poor internet connection, unavailability of technological gadgets along with it is the poor technical literacy of teachers. Despite the fact that substantial resources have been dedicated to implement technology in the classroom, many teachers have struggled with 
the disturbances that technologies can cause, have had their work negatively affected, or have not used technology effectively. These difficulties were manifested in the accounts of the informants of this study.

Poor internet connection. it refers to the essence of internet connection which entails to the difficulty of accessing internet linking in remote areas which centrals in the failure of the delivery of verbal instruction. Online synchronous teaching is a mode of teaching that utilizes video conferencing, live chat, instant messaging, or a combination of any of the online tools to engage learners to work in real-time. These materials are designed for collaborative tasks to engage learners on virtual collaboration among peers. Although Kalilangan National High School is adapting Blended learning a need to used asynchronous teaching is also important in the field of teaching Physical Education. This could help teachers in the skill performances of the learners. Physical activities of the students can be better assessed if the teacher uses virtual learning.

Although, the technical requirements of online teaching are far greater than traditional in-class teaching for inexperienced faculty members and also to student who live in area were internet connection is not possible (Wei Bao, 2020), teachers in Kalilangan National High School were also challenge on the teaching Physical Education when it comes to online methods due to poor internet connection. Supposed this online interaction to students could help teachers do online connections to the learners especially in terms of performance task, doing reinforcement and follow up their learnings regarding the lesson in Self-learning Modules. They suffer from doing it base on their accounts.

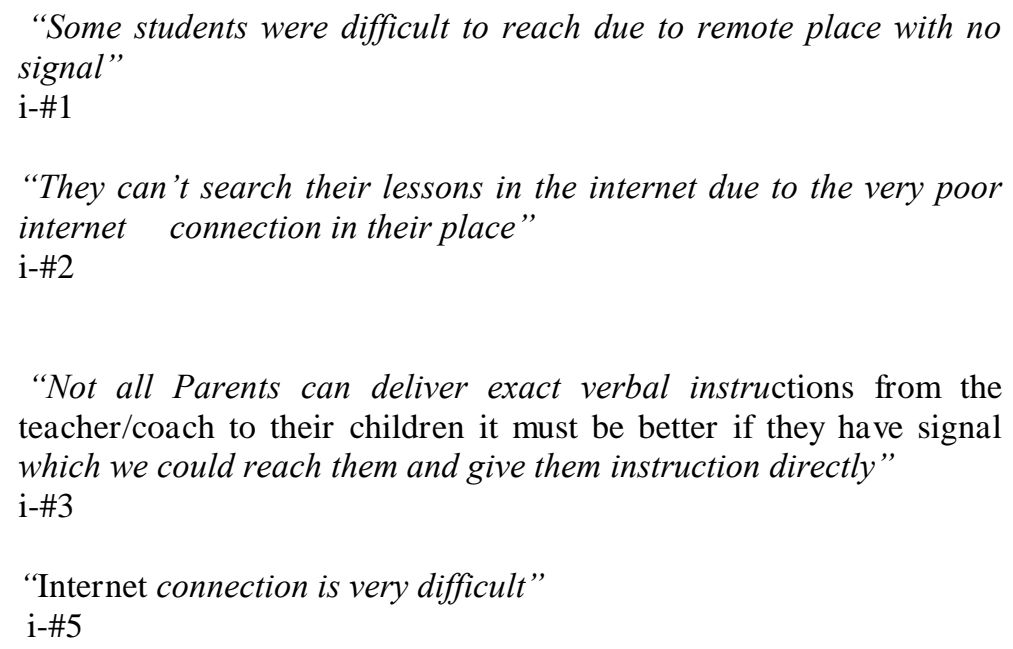

Individual differences seem to play an important role (Asmundson and Taylor, 2020). The Many Chinese college students have shown weak persistence in online learning, which seriously restricted their learning effectiveness $(\mathrm{Li}, \mathrm{Wu}, \mathrm{Yao}, \& \mathrm{Zhu}, 2013$. The Department of Education were never blind to this regards thus put into motion the Alternative Delivery Modes of learnings. Modes of learning are a set of guidelines that describe the methods humans use to acquire, process, and maintain knowledge. DepEd Order No. 008 were being issued to the different regions to guide them pertaining to the enrolment and suggested delivery modes to be implemented in the different schools.

Because of the internet, the current educational method has shifted. It is also used by teachers to complement classes, interact with pupils, and even hold online lectures and courses. The internet connection 
can contribute through lesson enhancement, teachers use the internet to give students extra resources, study materials, and educational games. Therefore, the quality of the educational process gets much better. Internet to some students also can be a source of income especially working students like networking and live selling. Very often, students get assignments that they cannot complete due to the lack of time, energy and knowledge, and this is where the internet can come in handy. However, not all students have access to technological resources.

This study suggests that teacher should be more flexible to take into considerations the different situation the learners were in, by any means finding more resources to deliver quality learning despite pandemic situation. Students on the other hand, should be provided with wide learning opportunities to learn and explore using Self Learning Module (SLM). Online teaching is not only the method of delivering learning besides understanding the different delivery modes could also be beneficial to learning process to deliver quality education, to marginalized students and those at risk of dropping out in order to help them overcome personal, social and economic constraints in their schooling.

Unavailability of technological gadgets. Is generally defined as the difficulties in achieving highend devices like laptops and mobile phone because of its necessity, technological gadgets that are available and intended to support online Learning and researches purposes. The idea of using digital technologies to teach students from homes was introduced to continue with education. Teachers in field provides online lectures, online examinations, communications and interactions. However, some of our students don't have their own gadgets to use forcing some of them to go internet shops to support their learnings. Moreover, other informants articulated:

"Like for instance, in my grade 8 lesson there are cited links in the Modules that must be viewed online unfortunately, they can't watch because their phone is only keypad phones" ...they cannot explore even links provided in the modules"

I\#3

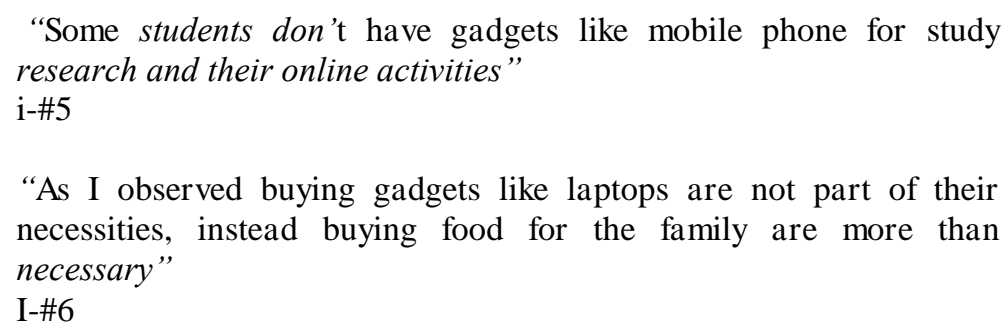

According to the work of Dewi Ratnasari and Haryanto (2019) due to various increased processing power, memory, and connectivity, which have made these technologies drastically more interactive, recent advances in ICT have significantly increased the possibilities of mobile phones being used as instructional tools (Pea \& Baldonado, 2006). Also, Smartphone is a collection of technological tools that have major applications that are required in daily life. It has incredible capacity, and it is used in conjunction with a mobile phone. Moreover, for most adolescents today mobile phones are the most important mode of communication. Classy smartphones can also be used to help students access information from the web, transform it, transfer it, collaborate with other students, and create a more media-rich approach to instruction. 
The importance of gadgets to education is very observant in this time of pandemic. This educational benefit could help teachers extend information more interesting and interactive in the learning system. Although teachers are in blended learning delivery which Self learning module is given more emphasis, teachers are trying their best in extending effort to deliver learning through to some students who have access to internet by providing them learning sources and cites to explore in a wider scope of resources.

The study implied that mobile gadgets can be an even more significant learning tool and a typically raised area in the near future. Therefore, mobile phone technologies can support students in their learning by exploring their world through these technologies. Curriculum planners and policy makers would be aware of the numerous possibilities of using mobile phone technologies in learning, so as to assist in implementing and designing activities to support the various learning needs. It also suggests that regardless of income or other circumstances, everyone should have equal access to such electronic tools, some schools work with businesses and other partners to create computer-lending programs for families. All schools should consider creating similar programs. The desired computers should also be available to parents at a variety of public settings such as schools, libraries, and government buildings, and there should be free or low-cost classes to teach educators and parents how to use them to foster learning.

Poor Technical literacy. This refers to the difficulties encountered by the teachers that needs assistance in the use of gadgets, ICT integration in the lesson and the insufficiency of experiences in the Radio-broad Instruction. Teachers in Kalilangan National High School have to adjust to this new leaning delivery mode aside from the Self Learning Module also they find it difficult in using the technological gadgets to be use for students learning. This is challenges encountered are manifested on the informants' narrative account.

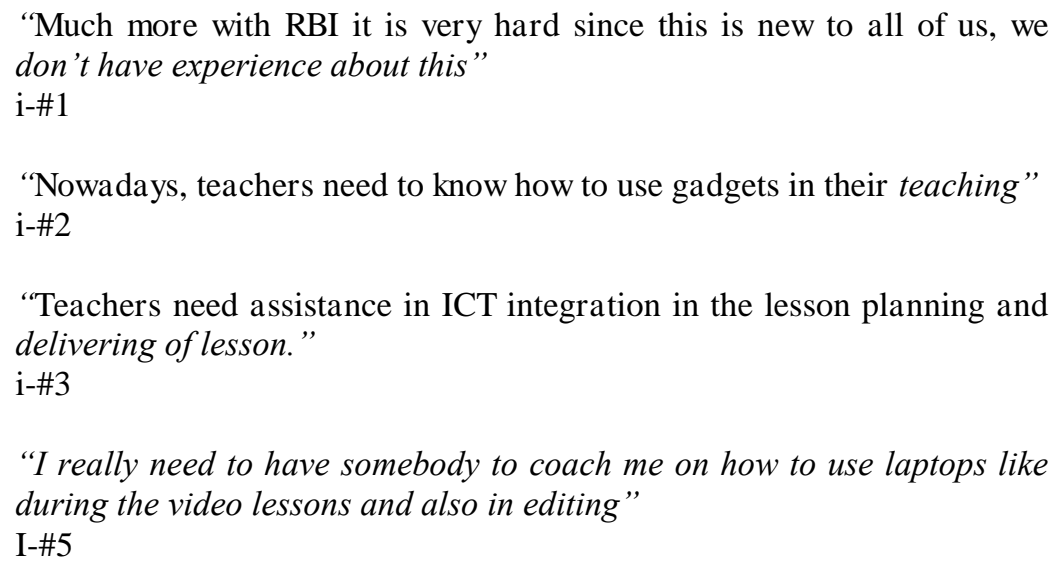

The present situation leads all educational institutions to start a class, where educators were forced to teach and prepare everything in a short period of time. All this leads teacher to suffer and it added much burdens even lack of social emotional competencies to cope with such situations (Hadar et al. 2020). Furthermore, in the most studies about ICT educators have a very significant role in the effective delivery of ICT meaningfully in the classroom.

This is an emergent gap (technical gap) in the system of education. Yet in this present pandemic situation, virtual classrooms have become an opening of hope to the educational system, it has also been tough for teachers when it comes to using it in their actual situation. Not everybody is capable of 
manipulating computers there were also aged teachers in the department who needs assistance in ICT. Although, teachers and students in a variety of fields have shown that electronic information systems provide excellent opportunities. Teachers can access required information on learning instruction materials through the internet thanks to the use of electronic information systems.

The study suggests that there's a need to focus on the methodological integration of ICT as well as technical support directly relevant for educators' teaching practice to improve the delivery of learning. Also, an advance training for teachers in the radio-broad instructions could provide knowledge and skills to support learning. Teacher should be more prepared giving the ample time of preparation before the conduct of instruction can be resulted to a better and meaning learning experiences for the students.

\section{Proposed Intervention Plan}

\section{Rationale}

Physical education is an essential part of healthy living for people of all age groups. Physical education teachers are responsible for this education because they are considered physical activity expert. They are important because they help students learn the importance of physical activity and how it contributes to their overall health and wellness.

Based on the result of the study, teachers are greatly affected by the-19 pandemic relative to the teaching in the Blended Learning Approach. Along with it is the teaching-learning experiences and challenges encountered in the Learning Support System. They were confronted with the following challenges: poor internet connection, the quality learning Outputs, availability of gadgets (cell phones and laptops) and the parent's involvement and support. These challenges had pushed me to formulate and develop a proposed intervention plan to address these pressing issues of the Teachers teaching Physical Education in Kalilangan National High School.

\section{Objectives} following:

This proposed intervention plan for the Physical Education Teachers and aims to achieve the

1. Identify the challenges encountered by the Physical Education teachers in Blended learning Approach in teaching Physical Education during health crisis.

2. To plan an effective strategy to help teachers in their struggles this time of pandemic.

3. To implement the proposed Intervention plan for teachers teaching become productive and effective in the teaching-learning process.

\section{Plans of Implementation}

1. Present this Proposed implementation to the professor and the panel members of this course for review and approval.

2. The proposed Intervention Plan will be presented to the administrators of Kalilangan National High School for Approval and adoption.

3. Conduct school-based orientation on the Utilization of proposed intervention plan.

4. Provide a copy of approved Proposed Intervention Plan to all Physical Education Teachers of Kalilangan National High School. 
A Proposed Intervention Plan on the Challenges Encountered by Physical Education Teachers on Blended Learning Approach in Teaching Physical Education in times of COVID-19 Pandemic

\begin{tabular}{|c|c|c|c|c|c|}
\hline $\begin{array}{l}\text { Area of } \\
\text { Concern }\end{array}$ & $\begin{array}{l}\text { Goals } \\
\text { Objectives }\end{array}$ & Activities & $\begin{array}{l}\text { Persons } \\
\text { involved }\end{array}$ & $\begin{array}{l}\text { Source } \\
\text { of } \\
\text { Budget }\end{array}$ & $\begin{array}{l}\text { Success } \\
\text { Indicato } \\
\mathbf{r}\end{array}$ \\
\hline \multirow[t]{2}{*}{$\begin{array}{l}\text { 1. Poor } \\
\text { Internet } \\
\text { connection }\end{array}$} & $\begin{array}{l}\text { To train teachers } \\
\text { to become more } \\
\text { innovative in } \\
\text { delivering } \\
\text { instructions using } \\
\text { other modality of } \\
\text { blended learning } \\
\text { in reaching out } \\
\text { students having } \\
\text { poor internet } \\
\text { connection. }\end{array}$ & $\begin{array}{l}\text { 1.1conduct a } \\
\text { Seminars on the } \\
\text { teaching- } \\
\text { learning } \\
\text { Modalities } \\
\text { before the } \\
\text { classes starts }\end{array}$ & $\begin{array}{l}\text { All teachers } \\
\text { and School } \\
\text { administrators }\end{array}$ & $\begin{array}{l}\text { School } \\
\text { allocated } \\
\text { funds / } \\
\text { PTA } \\
\text { Funds }\end{array}$ & $\begin{array}{l}\text { Trained } \\
\text { teachers } \\
\text { in terms } \\
\text { of in the } \\
\text { delivery } \\
\text { Modes } \\
\text { for } \\
\text { learning }\end{array}$ \\
\hline & $\begin{array}{l}\text { To provide a free } \\
\text { internet access to } \\
\text { all the teachers } \\
\text { conducting online } \\
\text { classes }\end{array}$ & $\begin{array}{l}\text { 1.2Installation } \\
\text { of free internet } \\
\text { connection for } \\
\text { teachers in the } \\
\text { different } \\
\text { Department. }\end{array}$ & $\begin{array}{l}\text { Teachers and } \\
\text { School } \\
\text { Admin. }\end{array}$ & $\begin{array}{l}\text { School } \\
\text { Allocated } \\
\text { Funds } \\
\text { MOOE }\end{array}$ & $\begin{array}{l}\text { Function } \\
\text { al free } \\
\text { internet } \\
\text { connectio } \\
n \text { in } \\
\text { every } \\
\text { Departm } \\
\text { ent }\end{array}$ \\
\hline $\begin{array}{l}\text { 2. Poor } \\
\text { Quality } \\
\text { Output }\end{array}$ & $\begin{array}{l}\text { To provide } \\
\text { support to } \\
\text { students in the } \\
\text { completion of } \\
\text { their learning } \\
\text { outputs }\end{array}$ & $\begin{array}{l}\text { 2.1Weekly } \\
\text { Monitoring of } \\
\text { students or } \\
\text { peer-to peer } \\
\text { communication }\end{array}$ & $\begin{array}{l}\text { Teacher and } \\
\text { students }\end{array}$ & $\begin{array}{l}\text { PTA } \\
\text { Funds }\end{array}$ & $\begin{array}{l}\text { Students } \\
\text { were } \\
\text { actively } \\
\text { engaged } \\
\text { in } \\
\text { learning } \\
\text { through } \\
\text { complete } \\
\text { submissi } \\
\text { on of } \\
\text { their } \\
\text { outputs. }\end{array}$ \\
\hline
\end{tabular}




\begin{tabular}{|c|c|c|c|c|c|}
\hline & $\begin{array}{l}\text { To reach out } \\
\text { students } \\
\text { especially remote } \\
\text { area ensuring } \\
\text { safety of the } \\
\text { teachers strictly } \\
\text { observing the } \\
\text { health protocols }\end{array}$ & $\begin{array}{l}2.2 \text { Home } \\
\text { Visitations } \\
\text { observing } \\
\text { health protocols }\end{array}$ & $\begin{array}{l}\text { Teacher and } \\
\text { students }\end{array}$ & $\begin{array}{l}\text { PE } \\
\text { teacher } \\
\text { Funding }\end{array}$ & $\begin{array}{l}\text { Submissi } \\
\text { on of } \\
\text { complete } \\
\text { and } \\
\text { quality } \\
\text { learning } \\
\text { output }\end{array}$ \\
\hline \multirow[t]{2}{*}{$\begin{array}{l}\text { 3.Availabilit } \\
\text { y of gadgets } \\
\text { like (Mobile } \\
\text { Phones and } \\
\text { Laptop, etc.) }\end{array}$} & $\begin{array}{l}\text { To be able to } \\
\text { provide technical } \\
\text { support through } \\
\text { an educational } \\
\text { access especially } \\
\text { to students } \\
\text { without gadgets. }\end{array}$ & $\begin{array}{l}4.1 \text { Putting a } \\
\text { radio site in the } \\
\text { different } \\
\text { barangays to } \\
\text { have access on } \\
\text { the radio-based } \\
\text { instruction }\end{array}$ & $\begin{array}{l}\text { LGU, } \\
\text { Barangay } \\
\text { Officials, } \\
\text { School } \\
\text { Administrator, } \\
\text { Teachers and } \\
\text { students }\end{array}$ & $\begin{array}{l}\text { LGU } \\
\text { Educatio } \\
\text { nal funds }\end{array}$ & $\begin{array}{l}\text { Installed } \\
\text { Radio } \\
\text { site for } \\
\text { education } \\
\text { al } \\
\text { Purposes }\end{array}$ \\
\hline & $\begin{array}{l}\text { To be able to } \\
\text { identify students } \\
\text { through a survey } \\
\text { for School-level } \\
\text { (Gift-Giving) } \\
\text { educational } \\
\text { assistance } \\
\text { Program for } \\
\text { Online Platforms. }\end{array}$ & $\begin{array}{l}\text { 4.2Giving } \\
\text { laptops and } \\
\text { mobile phones } \\
\text { to select } \\
\text { students of } \\
\text { KNHS }\end{array}$ & $\begin{array}{l}\text { Students and } \\
\text { teachers }\end{array}$ & $\begin{array}{l}\text { LGU- } \\
\text { Educatio } \\
\text { nal Funds } \\
\text { School } \\
\text { PTA } \\
\text { funds }\end{array}$ & \\
\hline \multirow[t]{2}{*}{$\begin{array}{l}\text { 5. Lack of } \\
\text { Parental } \\
\text { Support } \\
\text { and } \\
\text { Involve } \\
\text { ment }\end{array}$} & \multirow[t]{2}{*}{$\begin{array}{l}\text { To be able to } \\
\text { increase parent's } \\
\text { engagement and } \\
\text { strengthen the } \\
\text { home school } \\
\text { connections }\end{array}$} & $\begin{array}{l}\text { 3.1 Conduct an } \\
\text { Orientations } \\
\text { emphasizing } \\
\text { their importance } \\
\text { in the students } \\
\text { learning }\end{array}$ & $\begin{array}{l}\text { Parents and } \\
\text { teachers }\end{array}$ & $\begin{array}{l}\text { School } \\
\text { funds/PT } \\
\text { A }\end{array}$ & $\begin{array}{l}\text { Active } \\
\text { involvem } \\
\text { ent and } \\
\text { support } \\
\text { from } \\
\text { parents }\end{array}$ \\
\hline & & $\begin{array}{l}3.2 \text { personalized } \\
\text { communication } \\
\text { through social } \\
\text { media etc. } \mathrm{Fb} \\
\text { page, Parent } \\
\text { Group Chat, } \\
\text { cellular phones } \\
\text { and letter send } \\
\text { to parents }\end{array}$ & $\begin{array}{l}\text { Parents and } \\
\text { Teachers }\end{array}$ & $\begin{array}{l}\text { School } \\
\text { funds/PT } \\
\text { A }\end{array}$ & $\begin{array}{l}\text { Active } \\
\text { involvem } \\
\text { ent and } \\
\text { support } \\
\text { from } \\
\text { parents }\end{array}$ \\
\hline $\begin{array}{l}\text { 6. Technical } \\
\text { support for } \\
\text { Teachers }\end{array}$ & $\begin{array}{l}\text { To be able to } \\
\text { train teachers in } \\
\text { the technicalities } \\
\text { of using } \\
\text { technological } \\
\text { gadgets for } \\
\text { students learning. }\end{array}$ & $\begin{array}{l}\text { Conduct a } \\
\text { seminar } \\
\text { workshop of the } \\
\text { technicalities of } \\
\text { technological } \\
\text { gadgets for } \\
\text { synchronous } \\
\text { and }\end{array}$ & $\begin{array}{l}\text { Teachers and } \\
\text { IT expert }\end{array}$ & $\begin{array}{l}\text { School } \\
\text { Funding }\end{array}$ & $\begin{array}{l}\text { Compete } \\
\text { nt } \\
\text { teachers } \\
\text { in the use } \\
\text { technolo } \\
\text { gical } \\
\text { tools for } \\
\text { education }\end{array}$ \\
\hline
\end{tabular}




\begin{tabular}{|c|c|c|c|c|}
\hline & & $\begin{array}{l}\text { asynchronous } \\
\text { teaching }\end{array}$ & & . \\
\hline \multirow[t]{3}{*}{$\begin{array}{l}\text { 7. Lack of } \\
\text { communicati } \\
\text { on and } \\
\text { comprehensi } \\
\text { on }\end{array}$} & \multirow[t]{3}{*}{$\begin{array}{l}\text { To be able to } \\
\text { enhance teacher } \\
\text { engagement to } \\
\text { students and } \\
\text { Parents in } \\
\text { planning and } \\
\text { delivery of } \\
\text { learning } \\
\text { instructions }\end{array}$} & $\begin{array}{l}\text { Create a } \\
\text { Classroom } \\
\text { Management } \\
\text { Plan }\end{array}$ & $\begin{array}{l}\text { Teachers, } \\
\text { students and } \\
\text { Parents }\end{array}$ & $\begin{array}{l}\text { Better } \\
\text { engagem } \\
\text { ent of } \\
\text { teacher- } \\
\text { student, } \\
\text { Teacher } \\
\text { - Parent } \\
\text { in the } \\
\text { learning } \\
\text { process }\end{array}$ \\
\hline & & $\begin{array}{l}\text { Conduct } \\
\text { orientation/meet } \\
\text { ings every } \\
\text { quarter for } \\
\text { updates of } \\
\text { students' } \\
\text { progress and } \\
\text { improvements }\end{array}$ & $\begin{array}{l}\text { Teachers, } \\
\text { students and } \\
\text { Parents }\end{array}$ & \\
\hline & & $\begin{array}{l}\text { Constant } \\
\text { communication } \\
\text { to parents and } \\
\text { students } \\
\text { through Face to } \\
\text { face and Online } \\
\text { Communication } \\
\text { s }\end{array}$ & $\begin{array}{l}\text { Teachers, and } \\
\text { Parents }\end{array}$ & $\begin{array}{l}\text { On time } \\
\text { submissi } \\
\text { on of } \\
\text { complete } \\
\text { output }\end{array}$ \\
\hline
\end{tabular}

\section{Conclusion}

This study proves that this COVID -19 pandemic caused teacher to experience difficulties on Blended learning Approach in Physical Education. Indeed, every narrative accounts of the informants are a text to be read which attempted to ascertain the multiple facets of the challenges encountered by the Physical Education Teachers on Blended Learning Approach in Physical Education in times of COVID-19 Pandemic. It also turned out that these challenges encountered by the teachers can be address through an Intervention Program.

\section{Recommendation}

The following recommendations are offered: 
1. The administration should give importance in delivery of quality education and take into consideration the difficulties of the teacher in the Blended Learning Approach thus, intervention plan must be realized.

2. The utilization of the Proposed Intervention Plan must be shared and implemented to other nearby Schools who are experiencing same scenario.

3. Further, studies will be conducted parallel to this study. The following titles are suggested:

a. Impact of Online teaching to Academic Performance of the students.

b. Coping skills of teachers during COVID-19 Pandemic.

\section{References}

Aperribai L, Cortabarria L, Aguirre T, Verche E and Borges Á (2020) Teacher's Physical Activity and Mental Health During Lockdown Due to the COVID-2019 Pandemic. Front. Psychol. 11:577886. doi: 10.3389/fpsyg.2020.577886(2020). Coronavirusdisease (COVID-19): theneedtomaintainregularphysicalactivitywhiletakingprecautions.J. SportHealthSci.9,103-104.doi: 10.1016/j.jshs.2020.02.001

Berge, Z. L. (2013). BARIERS TO COMMUNICATION IN DISTANCE EDUCATION. Turkish Online Journal of Distance EducationTOJDE, 14.

Bingham, J. 1999, Guide to Developing Learning Outcomes, The Learning and Teaching Institute Sheffield Hallam University, Sheffield UK.

Braun V, Clarke V, Rance N. How to use thematic analysis with interview data. In: Vossler A, Moller N, editors. The counselling and psychotherapy research: London handbook. Sage; 2014. p. 183-97.

Chen, P. J., Mao, L. J., Nassis, G. P., Harmer, P., Ainsworth, B. E., and Li, F. Z.

Dewi Ratnasari and Haryanto, (2019), "Analysis of Utilization of Gadgets as Effective Learning Media in Innovation Education to improve Student Learning Achievement" in International Conference on Meaningful Education, KnE Social Sciences, pages 460-467. DOI 10.18502/kss.v3i17.467

Dewi Ratnasari and Haryanto. (2019). Analysis of Utilization of Gadgets as Effective. ICMEd, 2019.

Drucker, P. (2014). Innovation and entrepreneurship. Routledge.

Juan, G., Maria, P., Santos, V., et al. (2020) The effect of COVID-19Confinement in Behavioral, Psychological and Training Pattern of Chess Player. https://doi.org/10.3389/fpsyg.2020.01812

Keegan, D. (1986). The foundations of distance education. London: Croom Helm.

Morrow, R., Rodriguez, A. and King, N. (2015). Colaizzi's descriptive phenomenological method. The Psychologist, $28(8)$, 643-644.

O'Reilly, K. (2009). Interpretivism. In Key concepts in ethnography (pp. 119-124). SAGE Publications Ltd, https://www.doi.org/10.4135/9781446268308

Oyatzis, RE. Transforming qualitative information: thematic analysis and code development. Thousand Oaks: Sage; 1998.

Pea, R., \& Maldonado, H. (2006). WILD for learning: Interacting through new computing devices anytime anywhere. In Sawyer, K. (Ed.). Cambridge handbook of the learning sciences. New York: Cambridge University Press. 